Selected Writings of

THE

AMERICAN

\title{
TRANSCENDENTALISTS
}


This page intentionally left blank 


\section{Selected Writings of}

\section{THE \\ AMERICAN}

TRANSCENDENTALISTS

SECOND EDITION

Edited, with an Introduction by GEORGE HOCHFIELD

Yale University Press New Haven \& London 


\section{For Mayflower}

First published as a Signet Classic in 1966

Second Edition publisbed by Yale University Press in 2004

Copyright @ 1966, 2004 by George Hochfeld

All rights reserved. This book may not be reproduced, in wbole or in part, including illustrations, in any form (beyond that copying permitted by Sections 107 and 108 of the U.S. Copyright Law and except by reviewers for the public press), without written permission from the publisbers.

Printed in the United States of America.

Library of Congress Control Number: 2004106606

$$
\text { ISBN } 0-300-10281-X(p b k)
$$

A catalogue recond for this book is available from the British Library.

$$
10987654321
$$

